\title{
АКТУАЛЬНЫЕ ПРОБЛЕМЫ ПРИМЕНЕНИЯ ТРЕНИРОВОЧНЫХ СИСТЕМ В ПОДГОТОВКЕ БУДУЩИХ ВОЕННЫХ СПЕЦИАЛИСТОВ
}

\section{RELEVANT PROBLEMS OF APPLYING TRAINING SYSTEMS IN TEACHING FUTURE MILITARY SPECIALISTS}

\section{A. Bulokhov \\ M. Mikhaylov}

Summary: The substantiation of necessity to apply training systems in the military education is adduced in the article. Special attention is paid to the methodology of teaching future military specialists in the higher educational institutions. A summary of the recommended strength training exercises used for development of endurance and coordination is provided in the article.

Keywords: cadets, training systems, strength training exercises, CrossFit.
Булохов Александр Михайлович

Сотрудник, ФГКВОУ ВО Академия ФСО России (2. Орел) bam-4@yandex.ru

Михайлов Михаил Романович

к.т.н., Сотрудник, ФГКВОУ ВО Академия ФСО России

(2. Орел)

mmchailov@mail.ru

Аннотация: В статье приводится обоснование необходимости применения тренировочных систем в обучении военнослужащих. Уделено внимание методике проведения занятий с будущими военными специалистами, обучающимися в вузах. Раскрыто краткое содержание силовых упражнений, рекомендуемых военнослужащим для развития выносливости и координации.

Ключевые слова: курсанты, тренировочные системы, силовые упражнения, кроссфит.
$\mathrm{B}$ недрение ФГОС ВО (3++) в подготовку будущих военных специалистов в вузе потребовало от преподавателей не только построения учебных занятий, нацеленных на овладение курсантами профессиональными компетенциями, но и демонстрации своей профессиональной культуры и опыта, понимания сути важных образовательных проблем. Одной из таких актуальных проблем является применение на практике тренировочных систем, обеспечивающих развитие физических способностей будущих военных профессионалов. Вместе с тем, преподаватели военных вузов успешно внедряют в практику новые методы физической подготовки. Об этом можно судить по многочисленным публикациям в научных журналах и в материалах сборников различных конференций. Отметим, что новые методы физической подготовки военнослужащих основаны на развитии двигательных навыков, необходимых для той или иной воинской профессии. Еще до недавнего времени, как указывают в своих научных статьях ученые-педагоги, акцент был смещен в пользу общей физической подготовки: развитие быстроты, силы, выносливости и ловкости. Однако с позиции сегодняшнего времени уже становится понятно, что военнослужащему нужны развитые навыки и профессиональные компетенции, необходимые для выполнения той или иной задачи, по конкретной специальности. Конечно, и сейчас актуальны задачи формирования у сотрудников военно-прикладных навыков преодоления полос препятствий, различающихся как по сложности, так и по видам препятствий. Стоит отметить, что задача преодоления естественных и искусственных препятствий, а также овладение техникой их преодоления ставилась еще до появления первых фортификаци- онных сооружений, однако систематическое обучение началось только в 18-м столетии и было связано с изобретением огнестрельного оружия и, как следствие, увеличением расстояния поражения, что привело, в свою очередь, к изменению подхода в строительстве оборонительных сооружений. Первое руководство «Учение и хитрость ратного строения пехотных людей» было напечатано в Москве в 1647 году и уже содержало обучение преодолению препятствий. На рубеже 17-го и 18-го веков начала складываться национальная система боевой подготовки войск, что было связано с появлением регулярной армии, где обучению как передвижению, так и преодолению препятствий было уделено значительное внимание. Создание этой системы связано с такими прославленными именами, как Пётр Первый, Александр Васильевич Суворов, Пётр Александрович Румянцев и другие выдающиеся полководцы. Для всех воинских специальностей вводились и развивались такие аспекты, как плавание в обмундировании с оружием, приемы рукопашного боя с оружием и без него. Это остается важным и для сегодняшних военнослужащих. Но теперь в армейских структурах будут внедряться еще и комплексы упражнений, разрабатываемые для каждой военной специальности. К тому же повышается интенсивность и плотность занятий по физической подготовке, чему способствует создание таких комплексных систем, разработанных как для полевых условий, так и спортивных залов, мобильных спортивных комплексов и тренажёров, что значительно повышает их доступность. Подчеркнем, что в настоящее время появились, например, Армейские международные игры, которые способствуют популяризации развития специальных 
физических навыков. Примером международных соревнований, в которых участвовали две мужские и одна женская команды, и которые продемонстрировали отличную физическую подготовку российских военнослужащих, стали соревнования горных подразделений «Эдельвейс рейд - 2019» в Австрии, в которых россияне стали третьими и пятыми. Кроме вышеуказанных международных соревнований по военно-прикладным видам спорта следует отметить соревнования по видам войск, такие, как «Танковый биатлон», включающий индивидуальную гонку, спринт, гонку-преследование, спортивный этап и эстафету, причём спортивный этап включает в себя соревнование между экипажами, где проверяется состояние физической подготовки экипажей, и которая состоит из бега, силовых упражнений и полосы препятствий. По аналгии с «Танковым биатлоном», на волне его популярности, был создан «Авиадартс» - технический военно-прикладной вид спорта, который не содержит критерия скорость, а главным аспектом, подлежащим проверке, является точность. Продолжением этой тенденции стал такой вид военно-прикладного спорта, как «Открытая вода», в котором будут соревноваться понтонёры - представители вида войск, которые занимаются не только организацией переправ, но и разбором завалов и прокладкой дорог.

Кроме технических видов на национальном уровне существует триатлон специального назначения, который, как следует из названия, предполагает наличие трёх дисциплин, словосочетание «специальное назначение» указывает, что соревноваться между собой будут представители сил специального назначения. В состав этой комплексной дисциплины входит преодоление полосы препятствий в полной боевой выкладке, прикладная стрельба с ограничение информации об обстановке и «штурм высотки» - макета четырёхэтажного здания. Также к нетехническим видам прикладного спорта относится акватлон, который имеет советские корни (однако центр мирового акватлона сместился впоследствии в Израиль), его целью является не утопить соперника и заставить его сдаться с помощью болевого приёма или набрать больше очков в результате применения специальных приёмов и ударов, а пройти в специальные ворота, размещённые на определенной глубине, после чего необходимо дотянуться до одной из лент, закреплённых на теле соперника, схватить её и поднять первым над поверхностью воды.

Особое внимание следует также обратить на подготовку допризывной молодёжи. Наряду с возрождением комплекса ГТО, о котором речь пойдёт ниже, стоит обратить пристальное внимание на поднятие авторитета военно-прикладных видов спортивных игра, таких как «Зарница», «Орлёнок» или «Гонка Героев», «Тропа Мужества». Надо понимать, что основа качественного уровня физической подготовки закладывается в юном возрасте, что достигается комплексом мер поддержки, в том числе - повышение престижа спорта и здорового образа жизни у современной молодёжи [2].

Что касается подготовки курсантов в военных вузах страны, то в университетах, академиях и институтах, за последние пять лет, создана хорошая спортивная база, поистине соответствующая требованиям времени, где обучающиеся могут успешно тренироваться и достигать желаемых результатов. Однако поясним, что военнослужащие по роду своей деятельности и выполняемым должностным обязанностям могут находиться в разных условиях, иногда не позволяющим им осуществлять тренировки на стадионах, в спортивных залах и со специальным спортивным инвентарем. Поэтому руководителям физической подготовки в практических подразделениях, преподавателям в вузах, ученым, посвятившим свою жизнь развитию физической культуры и спорта, необходимо уделить особое внимание обучению военнослужащих оптимальным тренировочным системам, применимым в любых условиях службы и деятельности. О каких же тренировочных системах идет речь? Прежде всего, эти системы должны быть основаны на базовых движениях, которые могут иметь принадлежность к разным видам спорта [1]. Например, к гиревому спорту, легкой атлетике, спортивной гимнастике и т.д. Одной из таких тренировочных систем является кроссфит. Кроссфит, используемый как соревновательный вид спорта и как система физической подготовки, известен в мире с начала 2000-х годов (автор-создатель Грег Глассман).

Тренировки по такой системе включают в себя элементы интервальных тренировок высокой интенсивности, тяжёлой атлетики, пауэрлифтинга, гимнастики, гиревого спорта, бега и др. Кроссфит оптимально подходит для всех, кто заботится о своей физической форме, он хорош тем, что каждый, кто хочет тренироваться, сможет тренироваться где угодно и с любым набором оборудования. Концептуальной идеей кроссфита является функциональная направленность тренировок и максимальное их разнообразие. Важно и то, что кроссфит легко масштабируется под возможности каждого, все зависит от степени интенсивности и потребности организма в нагрузке. Интересно, что система кроссфит имеет предшественников, которые еще в 30-х годах прошлого века, должны были выполнять физкультурный комплекс «Готов к труду и обороне СССР» (ГТО). А в 60-е годы XX века этот комплекс пополнился ступенью «Готов к защите Родины». В настоящее время многие молодые люди знают о том, что можно развить силовые качества с использованием системы кроссфит. Если говорить о кроссфите, как о соревновательной дисциплине, то нужно сказать, что он получил широкое распространение в России, и в 2012 году был проведен первый чемпионат России, а уже на следующий год победители защищали честь России на чемпионате мира. 
В основе кроссфита лежит перекрёстный тренинг. Для развития силовых способностей применяются силовые упражнения, которые, в свою очередь, подразделяются на три группы, в основе которого лежит характер преодоления сопротивления. К первой группе относятся упражнения с весом собственного тела, ко второй изометрические упражнения и упражнения с внешним сопротивлением. Упражнения с внешним сопротивлением (гантели, штанга, гири, набивные мячи) характеризуются наибольшей эффективностью для развития силы, что, в сочетании с их правильным подбором и дозированием, позволяет развить все группы мышц без исключения. Упражнения с собственным весом (сгибание и разгибание рук в упоре лёжа, на брусьях и в висе на высокой и низкой перекладинах, лазание по канату, поднимание ног на брусьях и к перекладине) используются в подготовке сотрудников различных возрастных групп, пола и степени подготовленности. Часто используются легкоатлетические прыжковые упражнения (однократные и многократные прыжки на одной или двух ногах, прыжки через барьеры, прыжки в «глубину» с возвы- шения с последующим отталкиванием вверх, преодоление препятствий и др.). Изометрические упражнения подразделяются, в свою очередь, на упражнения с пассивным напряжением мышц (удержание груза на предплечьях рук, плечах, спине и т.п.) и упражнения с активным напряжении мышц (выпрямление полусогнутых ног, упираясь плечами в закрепленную перекладину и др.). Применяют такую методику и в некоторых военных вузах страны, где есть соответствующие специалистыспортсмены, ведущие занятия и дающие необходимые рекомендации курсантам [3]. Цель проведения таких занятий: формирование выносливости, гибкости, координации, скорости, силы. Кроссфит рассматривается многими преподавателями вузов как высокоинтенсивная тренировочная система функциональной физической подготовленности курсантов и студентов, включающая многофункциональные двигательные действия. Однако, для того, чтобы успешно внедрять тренировочные системы, преподавателям военных вузов необходимо обладать определённой степенью креативности.

\section{ЛИТЕРАТУРА}

1. Лебедев, В.А., Орлова, Е.Л., Юдин, А.В. Актуальные проблемы физического самовоспитания курсантов военного вуза // Современные проблемы науки и пути их решения: сборник научных статей. Выпуск 28. В 3 ч. Ч.2 .- Уфа: Омега Сайнс, 2016. - С. 153 - 156.

2. Михайлова, Ю.П., Михайлов, М.Р. 0 необходимости разработки актуальной методики определения личностных ценностей современной молодежи // Наука. Культура. Искусство: Актуальные проблемы теории и практики: сб. докл. Междунар. науч.-практ. конф.: в 4 т. / отв. ред. И.Е. Белогорцева, Ю.В. Бовкунова, С.И. Маматова. 2018. С. 72-77.

3. Ярославский, Д.И., Еганов, В.А. Кроссфит как средство физической подготовки курсантов летных вузов // Молодой ученый. - 2019. - № 51 (289). C. $480-482$. 